\title{
FAKTOR-FAKTOR YANG BERPENGARUH TERHADAP KEPUTUSAN PEMBELIAN SECARA ONLINE PADA MAHASISWA UNIVERSITAS GUNADARMA
}

\author{
Wardoyo $^{1}$, Intan Andini ${ }^{2}$ \\ Fakultas Ekonomi, Universitas Gunadarma \\ J1.Margonda Raya 100 Depok 16424 \\ Email: 1'wardoyo@Staff.Gunadarma.Ac.Id, ${ }^{2}$ intandini12@Gmail.Com
}

\begin{abstract}
The development of information technology and the Internet led to ease in transacting through web-based shopping sites, often referred to as online stores. The purpose of this study is to determine the influence of lifestyle, trust, ease and quality of information on purchasing decisions online. The object of this research is 130 students of Gunadarma University, independent variable includes lifestyle, trust, ease and quality of information, while the dependent variable is purchasing decision. Data analysis technique used is validity test, reliability test, f test, t test, linear regression Multiple. The results showed that lifestyle, ease of use, and quality of information positively affect purchasing decisions, while trust does not affect purchasing decisions. F test results showed lifestyle, trust, ease of use and quality of information together have an effect on to online purchasing at student of Gunadarma University.
\end{abstract}

Keywords: Lifestyle, trust, ease of use, quality of information, purchase decision, online store

\begin{abstract}
Abstrak
Perkembangan teknologi informasi dan internet menyebabkan kemudahan dalam bertransaksi melalui situs pembelanjaan yang berbasis web, yang sering disebut sebagai toko online. Tujuan dari penelitian ini adalah untuk mengetahui pengaruh gaya hidup, kepercayaan, kemudahan dan kualitas informasi terhadap keputusan pembelian secara online. Obyek dalam penelitian ini adalah 130 mahasiswa Universitas Gunadarma, variabel bebas meliputi gaya hidup, kepercayaan, kemudahan dan kualitas informasi, sedangkan variabel terikat adalah keputusan pembelian.Teknik analisis data yang digunakan adalah uji validitas, uji reliabilitas, uji f, uji t, Regresi linier berganda. Hasil penelitian menunjukkan bahwa gaya hidup, kemudahan penggunaan, dan kualitas informasi berpengaruh secara positif terhadap keputusan pembelian, sedangkan kepercayaan tidak mempengaruhi keputusan pembelian. Hasil uji F menunjukkan gaya hidup, kepercayaan, kemudahan penggunaan dan kualitas informasi secara bersama sama berpengaruh terhadap pembelian online pada mahasiswa Universitas Gunadarma.
\end{abstract}

Kata Kunci: Gaya hidup, kepercayaan, kemudahan penggunaan, kualitas informasi, keputusan pembelian, toko online 


\section{Pendahuluan}

Perkembangan teknologi telah mempermudah banyak hal diberbagai bidang salah satunya pada bidang ekonomi.Dalam bidang ekonomi internet menjadi salah satu media transaksi yang mempermudah pelaku ekonomi dalam menjalankan bisnis mereka sehingga faktor jarak dan waktu tidak lagi menjadi suatu permasalahan.Hal tersebut membuat banyak pelaku ekonomi mulai gencar menjadikan internet sebagai salah satu penunjang kegiatan bisnis mereka.Selain dapat menjalin hubungan bisnis dengan pelanggan secara lebih luas dan efisien, pelaku ekonomi juga dapat memangkas biaya-biaya yang seharusnya dikeluarkan. Hal inilah yang disadari sebagai peluang yang baik dalam menawarkan barang dan jasa kepada para konsumen melalui internet dalam pengaksesannya.

Perkembangan teknologi internet mempermudah masyarakat untuk berbelanja. Konsumen tidak perlu lagi untuk mendatangan pusat perbelanjaan atau took untuk berbelanja, namun cukup dengan menggunakan gawai (gadget)konsumen bisa berbelanja dengan mengunjungi berbagai situs web yang sering disebut dengan online shopping. Online shopping membuat kita semakin mudah berbelanja tanpa menghabiskan waktu dan tenaga karena kemudahan inilah membuat online shopping semakin diminati.Melalui online pembeli dapat melihat berbagai produk yang ditawarkan melalui web yang dipromosikan oleh penjual.Online shopping memungkinkan pembeli dan penjual untuk tidak bertatap muka secara langsung, sehingga hal ini memungkinkan penjual memiliki kesempatan mendapatkan pembeli dari luar negeri.

Sejak awal tahun 2012 perkembangan belanja online di Indonesia berkembang dengan pesat dan cepat.Meskipun banyak yang mengatakan pembelian online sangat high risk dalam pembayaran yang dilakukan sebelum pengiriman barang, namun dengan berbagai testimoni yang dimunculkan oleh pihak penjual dapat meyakinkan pembeli.
Kemudahan pembayaran juga sangat memudahkan dalam berbelanja melalui online shop.Pembeli cukup didepan komputer atau gadget barang akan tiba sendirinya melalui jasa pengiriman. Berkembangnya e-commerce beserta kemudahan dalam pembayaran memengaruhi keputusan pembelian online pada masyarakat, khususnya mahasiswa.

Ada beberapa faktor yang digunakan mahasiswa dalammelakukan pembelian secara online, diantaranya adalah kepercayaan, gaya hidup, kemudahan dan kualitas informasi. Bertransaksi secara online memiliki kepastian dan informasi yang tidak simetris.Oleh sebab itu harus ada rasa saling percaya antara penjual dan pembeli Gefen (2002).Kepercayaan konsumen akane-commerce merupakan salah satu factor kunci melakukan kegiatan jual beli secara online Koufaris dan Sosa (2004). Kemudian kemudahan (ease of use) Davis (1989) mendefinisikan percieved ease of use sebagai keyakinan akan kemudahan penggunaan, yaitu tingkatan dimana user percaya bahwa teknologi/sistem tersebut dapat digunakan dengan mudah dan bebas dari masalah.Kualitas informasi (information quality)yang didefinisikan sebagai persepsi pelanggan terhadap kualitas informasi tentang produk atau layanan yang disediakan oleh sebuah website. Semakin berkualitas informasi yang diberikan kepada pembeli online, maka akan semakin tinggi minat pembeli online untuk membeli produk tersebut Park dan Kim (2003).

Menurut Pavlou dan Geffen dalam penelitian Baskara dan Hariyadi (2014) faktor yang sangat penting yang bisa mempengaruhi pembelian online adalah kepercayaan. Kepercayaan menjadi faktor kunci dalam setiap transaksi jual beli secara online. Dengan adanya kepercayaan maka konsumen akan melakukan pembelian, karena pembelian secara online sangatlah berbeda dengan pembelian tradisional. Dalam pembelian online pembeli tidak dapat menyentuh bahan pakaian dan hanya bisa melihat melalui gambar yang tersedia pada toko online.

Kualitas informasi melekat kepada 
produk atau jasa yang dijual.Informasi yang lengkap dan jujur merupakan hal yang sangat penting dalam melakukan pembelian ataupun penjualan melalui secara online karena antara penjual dan pembeli tidak saling ketemu dan barang yang diperdagangkan pun hanya bisa dilihat dari foto sehingga kualitas barangpun agak sulit untuk diprediksi apakah sesuai dengan keinginan pembeli. Semakin baik kualitas informasi yang diberikan akan menambah minat pembeli untuk melakukan pembelian secara online. Kepercayaan tinggi, dan kualitas informasi yang baik akan percuma jika tidak didukung dengan pelayanan yang baik. Menurut Kottler (2009) definisi pelayanan adalah setiap tindakan atau kegiatan yang dapat ditawarkan oleh suatu pihak kepada pihak lain, yang pada dasarnya tidak berwujud dan tidak mengakibatkan kepemilikan apapun. Baik atau tidaknya pelayanan sangat tergantung dari persepsi konsumen.Persepsi baik jika pelayanan yang diterima melebih harapan konsumen sebaliknya persepsi buruk jika pelayanan yang diterima tidak sesuai dengan harapan pembeli.

Kini Indonesia merupakan salah satu negara yang sedang tumbuh pesat dalam menggunakan e-commerce untuk menjalankan bisnis.Penelitian ini fokus pada penjulan produk fashion secara online. Adapun daftar online shop yang menjual produk fashion yang berbasis web menurut Kompas adalah : Zalora Indonesia (zalora. co.id), BerryBenka (berrybenka.com), HijUp (hijup.com), Hijabenka (hijabenka.com), VIPPlaza (vipplaza.com), MatahariMall (mataharimall.com), UP (iwearup.com), LocalBrand (localbrand.co.id), dan 8Wood (8woo.com)

Berdasarkan uraian tersebut, penelitian ini dilakukan dengan tujuan untuk untuk menganalisis pengaruh pengaruh gaya hidup, kepercayaan, kemudahan dan kualitas informasi terhadap keputusan pembelian, baik secara parsial (masing-masing) maupun secara simultan (bersama-sama).

\section{Kajian Pustaka}

Ada beberapa hal yang memengaruhi seseorang melakukan pembelian secaraonline.

\section{Belanja Online}

Turban et al. (2004), Katawetawaraks dan Wang (2011) menjelaskan bahwa belanja online adalah kegiatan pembelian produk (baik barang ataupun jasa) melalui media internet. Kegiatan belanja online meliputi kegiatan Business to Business (B2B) maupun Business to Consumers (B2C). Sementara pada penelitian kegiatan belanja online dikaitkan dengan B2C karena kegiatan pembelian yang dimaksudkan adalah kegiatan pembelian yang digunakan oleh konsumen sendiri, tidak dijual kembali.Kegiatan belanja online di sini adalah transaksi yang bersifat ritel dengan pembeli individu, sehingga belanja online di sini ada-lah sebuah keputusan pembelian yang dilakukan oleh individu secara online. Salah satu manfaat dalam belanja online adalah calon pembeli dapat melihat ter-lebih dahulu (produk) yang akan dibelinya melalui web yang ditawarkan oleh penjual. Kegiatan ini sering disebut dengan searching.

Belanja online dapat dilakukan dengan cara melakukan window shopping online pada webyang dituju. Kemudian, pembeli dapat mengeklik barang yang diinginkan. Setelah itu pembeli kemudian dibawa kepada jendela yang menampilkan tata cara pembayaran yang disepakati dan kemudian setelahnominal uang ditransfer, maka penjual akan mengirim barang melalui jasa pos dan sebagainya. Pembayaran dapat dilakukan baik menggunakan kartu debit, kartu kredit, PayPal, memotong pulsa pelanggan (untuk transaksi lewat $H P$ ), cek maupun $C O D$ (Cash On Delivery) yaitu pembayaran yang dilakukan ketika barang telahdikirim oleh penjual. Cash On Delivery biasanya dilakukan melalui tatap mukaantara penjual dan pembeli, penjual dapat menunjukkan barangnya sehinggapembeli yang tertarik bisa meneliti barang yang akan ia beli. 
Pembelian semacamini biasanya melakukan pembayaran secara langsung atau uang kontan. Selain tataplangsung antara penjual dan pembeli, $C O D$ ini bisa dilakukan antara kurir danpembeli biasanya penjual hanya akan melayani $C O D$ apabila daerah pembelimasih dapat dijangkau oleh penjual.

Kotler dan Armstong (2004) menjelaskan bahwa keputusan pembelian merupakan tindakan atau perilaku seseorang dalam melakukan keputusan untuk memilih suatu produk baik dari sisi jenis mau-pun kuantitas produk itu sendiri. Proses keputusan itu sendiri paling tidak ada lima tahapan meliputi penge-nalan kebutuhan, pencarian informasi, pengevaluasian alternatif, penentuan pembelian dan perilaku pembelian yang umumnya merupakan kepuasan atas pemilihan keputusan yang diambil.

\section{Gaya Hidup}

Gaya hidup merupakan gambaran bagi setiap orang yang mengenakannya dan menggambarkan seberapa besar nilai moral orang tersebut dalam masyarakat sekitarnya. Gaya hidup juga berkaitan erat dengan perkembangan zaman dan teknologi. Gaya hidup adalah pola hidup seseorang didunia yang diekspresikan dalam aktivitas, minat, dan opininya. Menurut Assael dalam Yuniarti (2015:26), gaya hidup menggambarkan "keseluruhan diri seseorang" dalam berinteraksi dengan lingkungannya. Menurut Minor dan Mowen dalam Yuniarti (2015:27), gaya hidup adalah menunjukkan cara orang hidup, cara membelanjakan uangnya, dan cara mengalokasikan waktu. Menurut Suranto dan Rismiati dalam Yuniarti (2015:27), gaya hidup adalah pola hidup seseorang dalam dunia kehidupan sehari-hari yang dinyatakan dalam kegiatan, minat, dan pendapat yang bersangkutan. Gaya hidup mencerminkan keseluruhan pribadi yang berinteraksi dengan lingkungan. Oleh karena itu, dapat disimpulkan bahwa gaya hidup adalah pola hidup seseorang yang dinyatakan dalam kegiatan, minat, dan pendapatannya dalam membelanjakan uangnya dan cara mengalokasikan waktu.

Gayahidupcenderungmengklasifikasikan konsumen berdasarkan variabel-variabel yaitu aktifitas, interest (minat), dan pendapat/ pandangan. Konsep gaya hidup konsumen sedikit berbeda dari kepribadian. Gaya hidup terkait dengan bagaimana seseorang hidup, bagaimana menggunakan uangnya dan bagaimana mengalokasikan waktu mereka. Kepribadian menggambarkan karakteristik terdalam yang ada dalam diri manusia. Kepribadian sering juga disebut cara seseorang berpikir, merasa dan berpresepsi. Walaupun kedua konsep itu berbeda, gaya hidup dan kepribadian sangat berkaitan.

Menurut Simmamora, Henry dalam Yuniarti (2015:30) gaya hidup mengukur aktivitas-aktivitas manusia dalam hal :

a. Bagaimana mereka menghabiskan waktunya.

b. Minat mereka, apa yang dianggap penting di sekitarnya.

c. Pandangan-pandangan baik terhadap diri sendiri, maupun terhadap orang lain.

d. Karakter-karakter pasar seperti yang telah mereka lalui dalam kehidupan, penghasilan, pendidikan dan dimana mereka tinggal.

Gaya Hidup merupakan konsep yang sangat penting dalam menganalisis perilaku konsumen dalam keputusan pembelian. Gaya hidup dimulai dengan mengidentifikasi tingkah laku (behavior) tentang minat, hasrat, dan pendapat konsumen.Gaya hidup adalah pola hidup seseorang dalam dunia kehidupan sehari-hari yang dinyatakan kedalam kegiatan, minat, dan pendapat yang bersangkutan Yuniarti (2015:27).Gaya hidup memperngaruhi perilaku seseorang dan pilihan konsumsi seseorang. Orang cenderung memilih produk, jasa, atau aktivitas tertentu karna hal tersebut diasosiasikan dengan gaya hidup tertentu. Hasan (2009:131) menyatakan 
bahwa faktor-faktor yang mempengaruhi perilaku konsumen salah satunya adalah gaya hidup (lifestyle). Faktor gaya hidup tersebut sangat penting dipelajari oleh perusahaan. Kegagalan program pemasaran banyak ditentukan oleh ketidak mampuan menerjemahkan faktor tersebut ke dalam desain produk, penentuan harga, positioning dan program komunikasi pemasaran. Dengan memahami perilaku pelanggan secara tepat, perusahaan akan mampu memberikan kepuasan secara tepat dan lebih baik kepada pelanggannya.

Berdasarkan kaitan antara variabel gaya hidup terhadap keputusan pembelian di atas, maka dapat dibuat hipotesis :

H1: Gaya Hidup berpengaruh positif terhadap keputusan pembelian secara online.

\section{Kepercayaan}

Dalam e-commerece, pelanggan jarang sekali bertemu dengan salesmanuntuk bertransaksi, untuk itu kepercayaan harus ditempatkan secara langsungdalam website e-retailer.Dalam penjualan secara tradisional, pelanggan dapatlangsung menilai perusahaan dari petunjuk-petunjuk fisik yang ada seperti besarkecilnya perusahaan, kebersihan, seragam sales, dan lain sebagainya. Lebih lanjut,penilaian dapat dilihat dari salesman itu sendiri, pengetahuannya tentang produk,kemampuannya menjal dan bahkan karakter personalnya seperti kejujuran,familiar atau tidaknya dengan pelanggan, pengalamannya dalam menjual produk.Dalam internet petunjuk-petunjuk ini dan hubungan dengan salesman tidak dapatterpenuhi dengan baik (Gefen, 2002). Untuk e-retailers, web sitedigunakansebagai sarana komunikasi dengan pelanggan, oleh sebab itu tampilandan bentuk web site sangatlah penting. Penampilanweb site secara profesional mengindikasikan bahwa perusahaan e-retailerberkompeten dalam menjalankan operasionalnya.Tampilan web-site yangprofessional memberikan pelanggan rasa nyaman, maka dengan begitu pelanggandapat lebih percaya dan nyaman dalam melakukan pembelian (Chen and Dhillon,2003).

Kepercayaan adalah kemauan seseorang untuk bertumpu pada orang lain dimana kita memiliki keyakinan padanya. Kepercayaan merupakan kondisi mental yang didasarkan oleh situasi seseorang dan konteks sosialnya. Ketika seseorang mengambil suatu keputusan, ia akan lebih memilih keputusan berdasarkan pilihan dari orang-orang yang lebih dapat ia percaya dari pada yang kurang dipercayai Moorman dalam Pranoto (2014:14). Donney dan Cannon (2005:54), menyatakan bahwa kepercayaan merupakan suatu proses menghitung (calculative process) antara biaya yang dikeluarkan dengan hasil yang diperoleh. Hubungan jangka panjang akan meningkatkan tingkat trust pelanggan terhadap harapan yang akan diterima perusahaan sehingga akan mengurangi kegelisahan pelanggan terhadap pelayanan yang diterima Donney dan Cannon (2005:99). Kepercayaan pelanggan dipengaruhi dengan apa yang telah diterima dan dialami pelanggan (customer perceived value). Berdasarkan definisi diatas, maka dapat dinyatakan bahwa kepercayaan adalah rasa yang timbul terhadap suatu pihak untuk melakukan suatu kewajiban sesuai dengan yang diharapkan. Demikian halnya dengan kepercayaan yang timbul pada transaksi jual beli online akan menimbulkan minat seseorang untuk melakukan pembelian secara online.

Trust adalah kepercayaan pihak tertentu terhadap yang lain dalam melakukan hubungan transaksi berdasarkan suatu keyakinan bahwa orang yang dipercapainya tersebut akan memenuhi segala kewajibanya secara baik sesuai yang diharapkan. Kepercayaan adalah kemauan seseorang untuk bertumpu pada orang lain dimana kita memiliki keyakinan padanya. Kepercayaan merupakan kondisi mental yang didasarkan oleh situasi seseorang dan konteks sosialnya. Menurut Rousseau et.,al, dalam Suliantoro (2012), kepercayaan adalah wilayah psikologis yang merupakan perhatian untuk menerima apa adanya 
berdsarkan harapan terhadap perilaku yang baik dari orang lain. Kepercayaan konsumen didefinisikan sebagai kesediaan satu pihak untuk menerima resiko dari tindakan pihak lain berdasarkan harapan bahwa pihak lain akan melakukan tindakan penting untuk pihak yang mempercayainya, terlepas dari kemampuan untuk mengawasi dan mengendalikan tindakan pihak yang dipercaya Mayer et.al, dalam Anggit (2010). Menurut Mayer et.al dalam Santoso (2012) faktor yang membentuk kepercayaan seseorang terhadap yang lain ada tiga yaitu kemampuan (ability), kebaikan hati (benevolence), dan integritas (integrity).

Kepercayaan memiliki arti bahwa pembeli percaya terhadap kemampuan penjual online apakah penjual online dapat menjamin keamanan ketika sedang melakukan transaksi pembayaran meyakinkan transaksi akan segera diproses. Keahlian ini terkait dengan kebradaan penjual onlne.Teknologi yang semakin berkembang, begitu pula modus penipuan yang berbasis teknologi pada online shopping juga ikut berkembang. Tidak sedikit pula penjual online fiktif yang menjual dan memasarkan produk yang fiktif pada situs-situs online shopping.Kepercayaan adalah mental atau verbal pernyataan yang mencerminkan pengetahuan khusus seseorang dan penilaian tentang beberapa ide atau hal Scciffman dan Kanuk (2000).Setiap konsumen memiliki tingkat kepercayaan yang berbeda ada yang memiliki tingkat kepercayaan lebih tinggi dan ada pula yang memiliki tingkat kepercayaan yang lebih rendah.Hal tersebut disebabkan oleh kepercayaan konsumen menyangkut kepercayaan bahwa suatu produk memiliki berbagai atribut dan manfaat dari berbagai atribut tersebut.Kepercayaan konsumen terhadap suatu produk, atribut dan manfaat produk menggambarkan persepsi konsumen. Bertransaksi secara online memiliki kepastian dan informasi yang tidak simetris. Oleh karena itu jika konsumen medapatkan pengalaman yang baik saat bertransaksi secara online dan merasa yakin akan keamanannya ketika melakukan transaksi online ataupun belanja online di sebuah online shopping, maka konsumen cenderung untuk melakukan keputusan pembelian yang lebih tinggi pada situs online shopping tersebut. Beberapa penelitian terdahulu tentang kepercayaan (trust) menunjukkan hasil bahwa kepercayaan berpengaruh positif terhadap keputusan pembelian website.Menurut penelitian Rofiq (2007) dengan menggunakan metode Structural Equation Model (SEM) menyimpulkan bahwa kepercayaan(trust) pelanggan merupakan variabel yang sangat penting dalam mempengaruhipartisipasi pelanggan e-commerce di Indonesia. Berdasarkan kaitan antara variabel kepercayaan terhadap keputusan pembelian online di atas, maka dapat dibuat hipotesis :

H2: Kepercayaan berpengaruh positif terhadap keputusan pembelian secara online.

\section{Kemudahan}

Davis et.al.dalam Hardiawan (2013) mendefinisikan bahwa kemudahan merupakan seberapa besar teknologi komputer dirasakan relatif mudah untuk dipahami dan digunakan. Faktor kemudahan ini terkait dengan bagaimana operasional bertransaksi secara online.Kemudahan merupakan hal terpenting yang harus diperhatikan oleh para penyedia atau penjual online. Kemudahan ini bisa jadi levelnya beragam, tergantung juga dari pengguna atau pembeli itu sendiri tetapi tentu pada dasarnya ada standar kemudahan yang level-nya sama di semua pengguna. Pembelian online biasanya dibandingkan dengan pembelian offline, apa yang ditawarkan dalam pembelian online biasanya harus lebih baik dari apa yang ditawarkan dalam pembelian offline, kemudahan sering menjadi salah satu daya tarik. Dari kemudahan mengakses pilihan barang, kemudahan dalam melakukan pembelian, kemudahan pembayaran sampai dengan kemudahan mendapatkan barang atau pengiriman.Internet yang memungkinkan akses atas toko dari manapun adalah salah satu contoh sederhana dari kemudahan yang ditawarkan penyedia e-commerce, calon pembeli kini bisa mengakses toko dari mana 
saja di laptop, PC atau perangkat bergerak, baik itu smartphone atau tablet. Keputusan pembelian pun tidak lagi harus dilakukan di toko ketika melihat barang, bisa saja pengguna melihat barang ketika menunggu di kafe, lalu memutuskan untuk membeli ketika sampai di tempat tujuan lain. Proses pembayaran pun harus dipermudah, artinya calon konsumen diberikan fasilitas dan alur cara pembayaran yang membuat kenyamanan dalam melakukan pembelian jadi yang utama. Bisa jadi ini akan berpengaruh pada pilihan cara pembayaran, mulai dari transfer antar bank, dengan debit, kartu kredit atau cara pembayaran lain. Ada juga kemungkinan toko online atau penyedia layanane-commerce tidak menyediakan secara lengkap cara pembayaran dari toko mereka, namun seiring pertumbuhan konsumen serta kebutuhan mereka, bisa jadi nantinya semua cara pembayaran harus tersedia di layanan e-commerce tersebut.

Kemudahan merupakan hal terpenting yang harus diperhatikan oleh para penyedia atau penjual online.Kemudahan adalah sesuatu yang dapat mempermudah dan memperlancar usaha. Davis et. al. dalam Hardiawan (2013) mendefinisikan bahwa kemudahan merupakan seberapa besar teknologi komputer dirasakan relatif mudah untuk dipahami dan digunakan. Faktor kemudahan ini terkait dengan bagaimana operasional bertransaksi secara online. Kemudahan merupakan hal terpenting yang harus diperhatikan oleh para penyedia atau penjual online agar para konsumen dapat dengan mudah mengakses dan mengaplikasikan situs web online shop tersebut untuk berbelanja. Menurut penelitian Hardiawan (2013) dengan menggunakan metode Analisis data statistic menyimpulkan bahwa kemudahan berpengaruh positif dan signifikan terhadap keputusan pembelian melalui uji $\mathrm{F}$ dan uji $\mathrm{T}$. Berdasarkan kaitan antara variabel kemudahan terhadap keputusan pembelian di atas, maka dapat dibuat hipotesis:

H3: Kemudahan berpengaruh positif terhadap keputusan pembelian secara online.

\section{Kualitas Informasi}

Raymond McLeod dalam Yuniarti (2015:114), menyatakan bahwa informasi adalah data yang telah diolah menjadi bentuk yang memiliki arti bagi penerima dan bermanfaat bagi peengambilan keputusan saat ini atau mendatang.Didalam online shopping sebaiknya menyajikan informasi yang mencakup kaitannya dengan produk dan jasa yang ada pada online shopping. Informasi tersebut sebaiknya berguna dan relevan dalam memprediksi kualitas dan kegunaan produk atau jasa.Informasi produk dan jasa harus up-to-date untuk memuaskan kebutuhan konsumen atau pembeli online.Hal tersebut dapat membantu pembeli didalam membuat keputusan, konsisten dan mudah dipahami. Kualitas informasi adalah sejauh mana informasi secara konsisten dapat memenuhi persyaratan dan harapan semua orang yang membutuhkan informasi tersebut untuk melakukan proses mereka. Konsep ini dikaitkan dengan konsep produk informasi yang menggunakan data sebagai masukan dan informasi didefinisikan sebagai data yang telah diolah sehingga memberikan makna bagi penerima informasi (Wikipedia, 2013). Menurut Yuniarti (2015:117), pada prinsipnya, kualitas informasi bergantung pada tiga hal, yaitu informasi harus akurat, tepat waktu, dan relevan.

a. Akurat (accuracy), yaitu informasi harus mencerminkan keadaan yang sebenarnya, informasi harus bebas dari kesalahan.

b. Tepat waktu (timeliness), yaitu informasi yang datang kepada penerima tidak boleh terlambat. Informasi yang sudah usang tidak akan mempunyai nilai lagi. Karena informasi merupakan landasan dalam pengambilan keputusan.

c. Relevan (relevancy), berarti informasi tersebut mempunyai manfaat bagi pemakainya.

Kualitas informasi didefinisikan sebagai persepsi pelanggan terhadap kualitas 
informasi tentang produk atau layanan yang disediakan oleh sebuah website Park dan Kim dalam Loo (2011).Informasi tersebut sebaiknya berguna dan relevan dalam memprediksi kualitas dan kegunaan produk atau jasa. Untuk memuaskan kebutuhan konsumen atau pembeli online akan informasi, maka informasi produk dan jasa harus up-todate, untuk membantu pembeli online dalam membuat keputusan, konsisten, dan mudah dipahami. Informasi produk pada online shopping mencakup informasi atribut suatu produk, rekomendasi dari para konsumen, laporan evaluasi, dll.Informasi atribut produk adalah informasi tentang spesifikasi produk, yaitu dimensi ukuran, dimensi warna, dimensi bahan, dimensi teknologi, dan harga dasar suatu produk.

Informasi adalah data yang diolah menjadi bentuk yang berguna untuk membuat keputusan.Informasi berguna untuk membuat keputusan karena informasi menurunkan ketidakpastian (meningkatkan pengetahuan). Menurut Sutabri dalam Yuniarti (2015:114), informasi adalah data yang telah diklasifikasikan atau diolah atau diinterpretasikan untuk digunakan dalam proses pengambilan keputusan. George Bodnar dalam Yuniarti (2015:115), informasi adalah data yang diolah sehingga dapat dijadikan dasar untuk mengambil keputusan yang tepat. Pada prinsipnya, kualitas informasi bergantung pada tiga hal yaitu, akurat, tepat waktu dan relevan. Semakin berkualitas informasi yang diberikan kepada pembeli online, maka akan semakin tinggi minat pembeli online untuk membeli produk tersebut. Menurut penelitian Naomi (2012) dengan menggunakan metode regresi linear berganda menyimpulkan bahwa kualitas informassi secara parsial berpengaruh positif dan signifikan terhadap keputusan pembelian secara online. Berdasarkan kaitan antara variabel kualitas informasi terhadap keputusan pembelian di atas, maka dapat dibuat hipotesis:

H4: Kualitas informasi berpengaruh positif terhadap keputusan pembelian secara online.

\section{Kerangka Pemikiran dan Hipotesis}

Berdasarkan kajian pustaka dan temuan penelitian sebelumnya, maka model dan hipotesis penelitian seperti pada Gambar 1.

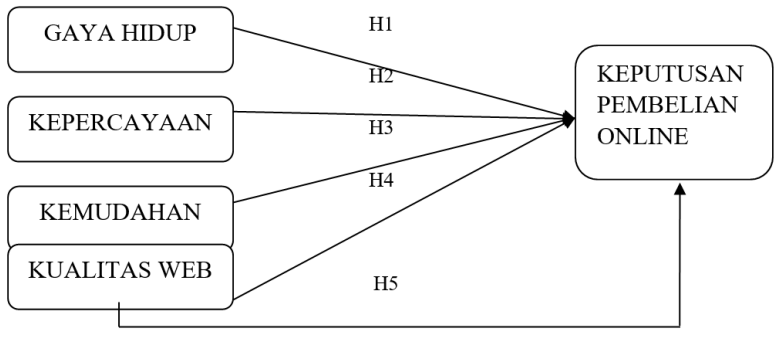

Gambar 1 Model Penelitian

Analisis regresi linier berganda digunakan untuk mengetahui pengaruh dua variabel bebas atau lebih terhadap satu variabel terikat Ghozali (2013). Berdasarkan gambar 1 maka persamaan matematisnya adalah sebagai berikut:

$$
\mathrm{Y}=\mathrm{A}+\beta \mathrm{IGH}+\beta 2 \mathrm{KP}+\beta 3 \mathrm{KM}+\beta 4 \mathrm{KI}+e
$$

\section{Keterangan :}

$\begin{array}{ll}\text { A } & : \text { Konstanta } \\ \beta 1, \beta 2, \beta 3, \beta 4 & : \text { Koefisien Regresi } \\ \text { GH } & : \text { Gaya Hidup } \\ \text { KP } & : \text { Kepercayaan } \\ \text { KM } & : \text { Kemudahan } \\ \text { KI } & : \text { Kualitas Informasi } \\ e & : \text { Standar eror }\end{array}$

\section{Metode Penelitian}

Obyek penelitian adalah mahasiswa Fakultas Ekonomi Universitas Gundarma angkatan 2014/2015. Data primer diperoleh dari responden melalui penyebaran kuesioner berupa profil responden, gaya hidup, kepercayaan, kemudahan dan kualitas informasi serta keputusan pembelian. Sampel diambil berdasarkan simple random sampling sebanyak 130 responden dari 26 kelas. Teknik analisis data yang digunakan adalah uji validitas, uji reliabilitas, uji $F$, uji t, serta regresi linier berganda. 


\section{Hasil Dan Pembahasan}

Bisnis e-commerce sedang marak sekali berkembang di Indonesia seiring dengan perkembangan teknologi pada saat ini.Dimana teknologi informasi elektronik sebagai penghubung antara perusahaan, konsumen, dan masyarakat dalam bentuk transaksi elektronik yang berupa pertukaran atau penjualan barang, servis, dan informasi secara elektronik.Salah satu bisnis e-commerce yang banyak berkembang di Indonesia adalah online shop yang menjual berbagai produk fashion melalui situs web, diantaranya ada, Zalora Indonesia (zalora. co.id), BerryBenka (berrybenka.com), HijUp (hijup.com), Hijabenka (hijabenka.com), VIPPlaza (vipplaza.com), MatahariMall (mataharimall.com), UP (iwearup.com), Maskoolin (maskoolin.com), LocalBrand (localbrand.co.id), 8Wood (8woo.com), dan masih banyak lainnya.

\section{Gambaran Umum Profil Responden}

Gambar 4.1 menunjukkan karakteristik responden berdasarkan domisili, dimana sebanyak 45 orang atau $35 \%$ responden berdomisili di Jakarta, sebanyak 55 orang atau $43 \%$ berdomisili di Depok, sebanyak 13 orang atau 10\% berdomisili di Bogor, sebanyak 2 orang atau $1 \%$ berdimisili di Tangerang, sebanyak 7 orang atau $5 \%$ berdomisili di Bekasi, dan sebanyak 8 orang atau $6 \%$ berdomisili dilainnya

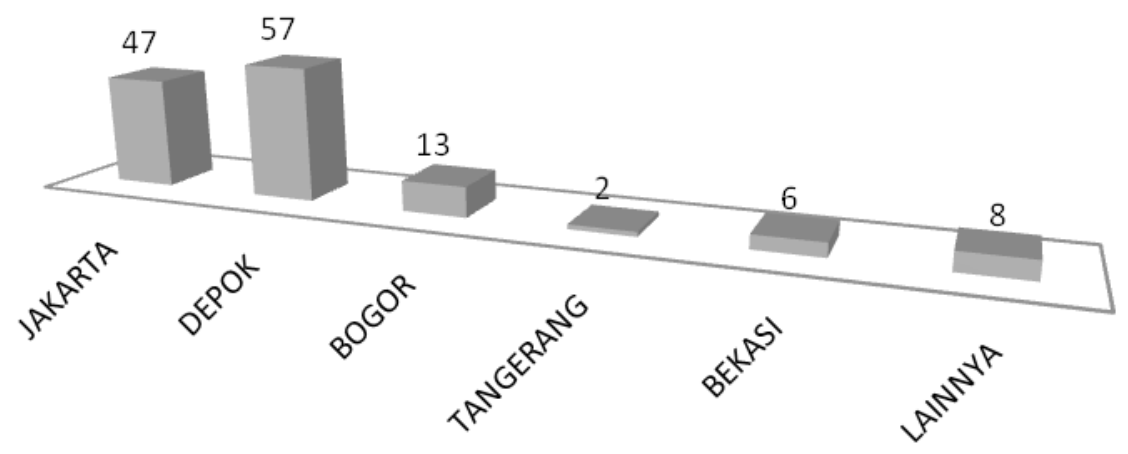

Gambar 4.1

Responden Berdasarkan Domisili

Sumber : Data Primer diolah, 2017

Gambar 4.2 menunjukkan karakteristik responden berdasarkan uang saku/bulan yang diberikan orangtua. Berdasarkan gambar 4.2 dapat dilihat uang saku $<$ Rp. 800.000 sebanyak 32 orang atau $25 \%$ responden, uang saku Rp. 800.000 - Rp. 1.500 .000 sebanyak
53 orang atau $41 \%$ responden, uang saku Rp. 1.600 .000 - Rp. 2.200 .000 sebanyak 18 orang atau $14 \%$ responden, uang saku Rp. 2.300 .000 - Rp. 3.000.000 sebanyak 16 orang atau $12 \%$ responden, dan uang saku $>$ Rp. 3.000 .000 sebanyak 11 orang atau $8 \%$. 


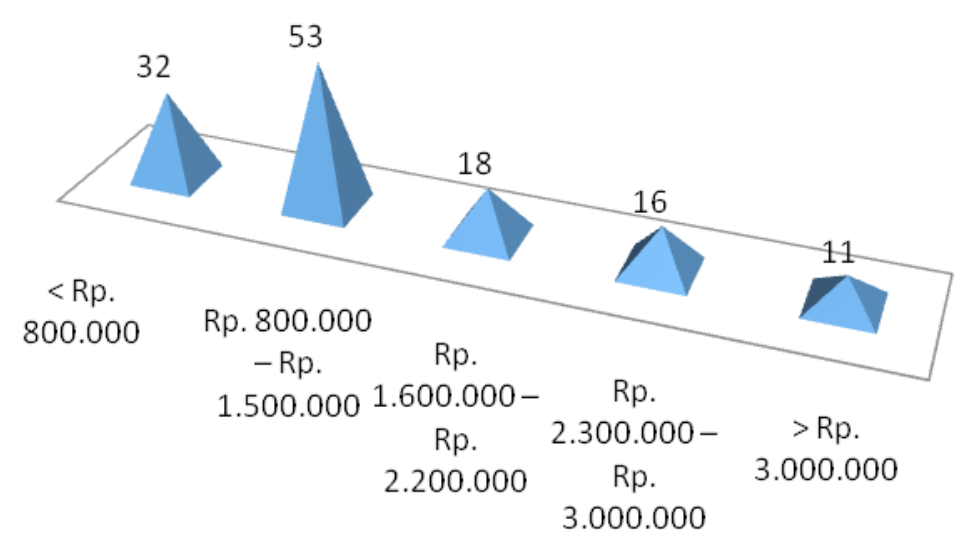

\section{Gambar 4.2}

\section{Responden Berdasarkan Uang Saku/Bulan}

Gambar 4.3 menunjukkan karakteristik responden berdasarkan intensitas pembelian dalam satu bulan. Berdasarkan gambar 4.6 dapat dilihat pembelian $<2$ kali sebanyak 35 orang atau $27 \%$ responden, pembelian 2 - 3 kali sebanyak 52 orang atau $40 \%$ responden, pembelian $4-5$ kali sebanyak 27 orang atau 21\% responden, pembelian $6-7$ kali sebanyak 11 orang atau $8 \%$ responden, dan $>7$ sebanyak 5 orang atau $4 \%$ responden. Gambar 4.4 menunjukkan karakteristik responden berdasarkan situs online shop yang sering digunakan untuk bertransaksi.

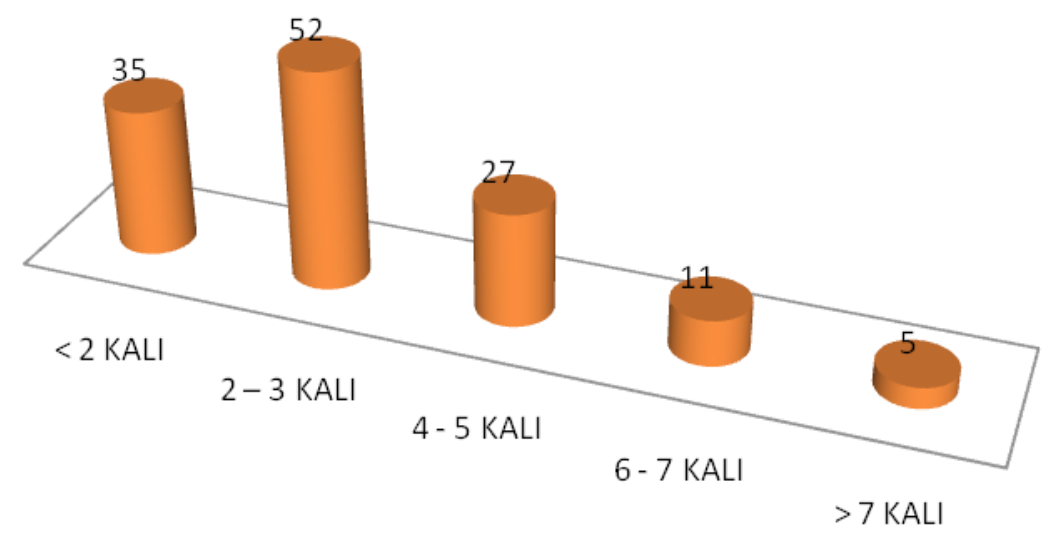

Gambar 4.3

Responden Berdasarkan Intensitas Pembelian Dalam Satu Bulan

Sumber : Data Primer diolah, 2017 


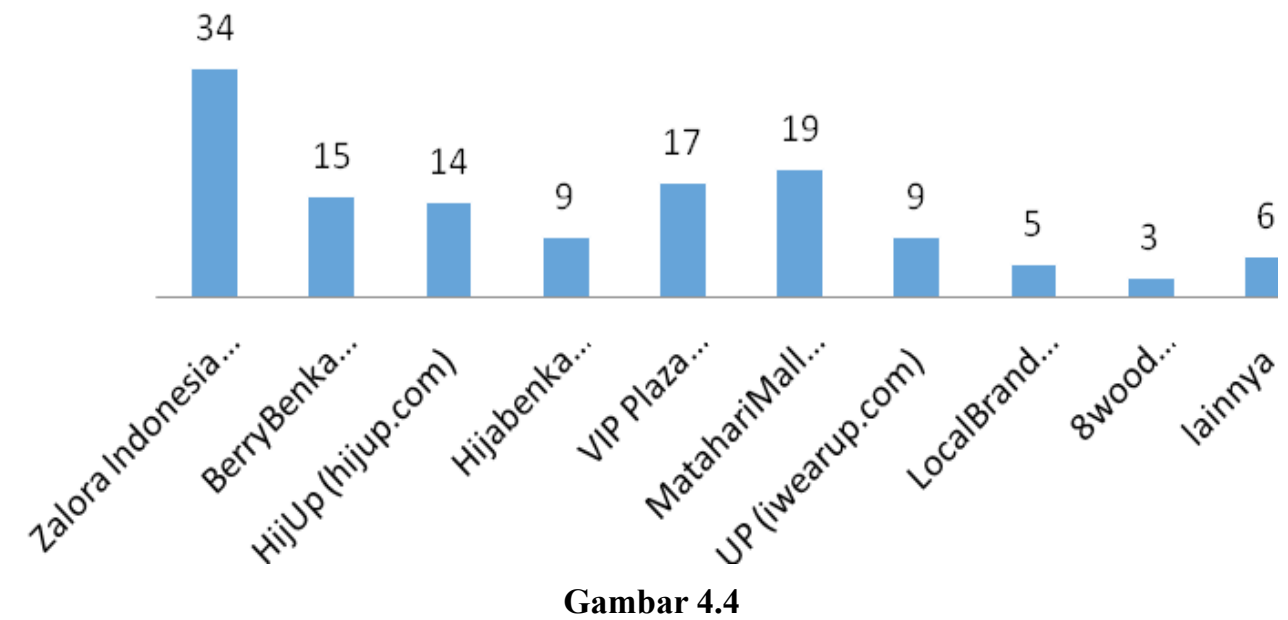

Responden Berdasarkan Situs Online Shop Yang Sering Digunakan Untuk Bertransaksi

Sumber : Data Primer diolah, 2017

Berdasarkan gambar 4.4 dapat dilihat situs web yang sering digunakan untuk bertransaksi Zalora Indonesia (zalora.co.id) sebanyak 33 orang atau $26 \%$ responden , BerryBenka (berrybenka.com) sebanyak 15 orang atau $14 \%$ responden,HijUp(hijup.com) sebanyak 14 orang atau 14\% responden, Hijabenka (hijabenka. com) 9 orang atau $7 \%$ responden, VIPPlaza (vipplaza.com) 17 orang atau $13 \%$ responden, MatahariMall (mataharimall.com) 19 orang atau $14 \%$ responden, UP (iwearup.com) 9 orang atau $7 \%$ responden, LocalBrand (localbrand.co.id) 5 orang atau 4\% responden, $8 \mathrm{Wood}$ (8woo.com) 3 orang atau $2 \%$ responden, dan lainnya sebanyak 6 orang atau $5 \%$ responden.

\section{Analisis Hasil Penelitian}

Nilai $r$ hitung diperoleh dari nilai Corrected Item-Total Correlation yang diolah menggunakan SPSS 22. Pengujian menggunakan tingkat kepercayaan sebesar 95\% atau alpha 0,05 dimana $\mathrm{df}=\mathrm{n}-2=$ $30-2=28$. Dengan $n=130$ dan alpha 0,05 maka diperoleh r-tabel $=0,361$. Berdasarkan hasil uji diperoleh hasil bahwa semua item pernyataan valid. Berdasarkan uji reliabilitas diperoleh hasil semua variable dinyatakan reliable karena nilai Cronbach's Alpha lebih besar dari 0,60.

Tabel 4.1 Hasil Analisis Regresi Linear Berganda

\begin{tabular}{|c|c|c|c|c|c|c|c|c|}
\hline \multicolumn{9}{|c|}{ Coefficients $^{\mathrm{a}}$} \\
\hline & \multirow{2}{*}{ Model } & \multicolumn{2}{|c|}{$\begin{array}{c}\text { Unstandardized } \\
\text { Coefficients }\end{array}$} & \multirow{2}{*}{$\begin{array}{c}\text { Standardized } \\
\text { Coefficients }\end{array}$} & \multirow{2}{*}{$\mathbf{t}$} & \multirow{2}{*}{ Sig. } & \multicolumn{2}{|c|}{ Collinearity Statistics } \\
\hline & & B & Std. Error & & & & Tolerance & VIF \\
\hline \multirow{5}{*}{1} & (Constant) & 1.026 & .668 & & 1.536 & .127 & & \\
\hline & GAYA HIDUP & .258 & .072 & .247 & 3.610 & .000 & .319 & 3.131 \\
\hline & KEPERCAYAAN & .070 & .093 & .062 & .757 & .451 & .221 & 4.523 \\
\hline & KEMUDAHAN & .289 & .077 & .326 & 3.740 & .000 & .197 & 5.075 \\
\hline & $\begin{array}{l}\text { KUALITAS } \\
\text { INFORMASI }\end{array}$ & .317 & .102 & .330 & 3.104 & .002 & .133 & 7.546 \\
\hline
\end{tabular}

a. Dependent Variable: KEPUTUSAN KONSUMEN 
Berdasarkan tabel 4.1diperoleh bentuk persamaan regresi adalah sebagai berikut :

$\mathrm{KP}=1,026+0,258 \mathrm{GH}+\mathbf{0 . 0 7 0} \mathrm{KP}+\mathbf{0 , 2 8 9}$ $\mathbf{K M}+\mathbf{0 , 3 1 7} \mathbf{K I}$

Dimana :

$\begin{array}{ll}\mathrm{a} & =\text { Konstanta } \\ \mathrm{b} 1, \mathrm{~b} 2, \mathrm{~b} 3, \mathrm{~b} 4 & =\text { Koefisien regresi } \\ \mathrm{GH} & =\text { Gaya Hidup } \\ \mathrm{KP} & =\text { Kepercayaan Kemudahan } \\ \mathrm{KM} & =\text { Kemudahan } \\ \mathrm{KI} & =\text { Kualitas Informasi }\end{array}$

KP $=$ Keputusan Pembelian

Table 4.2 Tabel Uji Anova (Ringkasan Uji F)

\begin{tabular}{|c|c|c|c|c|c|c|}
\hline \multicolumn{7}{|c|}{ ANOVA $^{\mathrm{a}}$} \\
\hline & Model & Sum of Squares & Df & Mean Square & $\mathbf{F}$ & Sig. \\
\hline \multirow{3}{*}{1} & Regression & 2152.440 & 4 & 538.110 & 135.598 & $.000^{\mathrm{b}}$ \\
\hline & Residual & 496.053 & 125 & 3.968 & & \\
\hline & Total & 2648.492 & 129 & & & \\
\hline \multicolumn{7}{|c|}{ a. Dependent Variable: KEPUTUSAN KONSUMEN } \\
\hline \multicolumn{7}{|c|}{$\begin{array}{l}\text { b. Predictors: (Constant), KUALITAS INFORMASI, GAYA HIDUP, KEPERCAYAAN, } \\
\text { KEMUDAHAN }\end{array}$} \\
\hline
\end{tabular}

Sumber : Data Primer diolah, 2017

Untuk melihat signifikansi pengaruh sehingga DF2 $=125$ dan didapat $\mathrm{f}$ tabel 2,29. variabel bebas terhadap variabel Dari hasil uji Anova pada tabel 4.2, diketahui terikat secara bersama-sama dan untuk hasilnya adalah dimana probabilitasnya sig mengetahuipersamaan regresi yang akan $0,000<0,05$ dan $\mathrm{f}$ hitung 135,598 $>\mathrm{f}$ tabel dibuat dapat dipakai atau tidak untuk 2,29 sehingga Ho ditolak dan Ha diterima. memprediksi variabel terikatnya, maka Artinya variabel Gaya Hidup, Keprcayaan, digunakan uji Anova. Pada penelitian ini, Kemudahan, Kualitas Informasi secara jumlah responden (n) sebanyak 130 dimana bersama-sama berpengaruh secara simultan DF1=K-1 artinya $\mathrm{K}$ adalah jumlah variabel terhadap Keputusan Pembelian online di $\mathrm{x}+\mathrm{y}$ sehingga $\mathrm{DF} 1=4$ dan $\mathrm{DF} 2=\mathrm{N}-\mathrm{K}$ Universitas Gunadarma.

Tabel 4.3

Koefisien Determinasi

\begin{tabular}{lcccc}
\hline \multicolumn{4}{c}{ Model Summary $^{\mathrm{b}}$} \\
\hline Model & $\mathbf{R}$ & R Square & Adjusted R Square & $\begin{array}{c}\text { Std. Error of the } \\
\text { Estimate }\end{array}$ \\
\hline 1 & $.902^{\mathrm{a}}$ & .813 & .807 & 1.992 \\
\hline $\begin{array}{l}\text { a. Predictors: (Constant), KUALITAS INFORMASI, GAYA HIDUP, KEPERCAYAAN, } \\
\text { KEMUDAHAN }\end{array}$ \\
b. Dependent Variable: KEPUTUSAN KONSUMEN \\
\hline
\end{tabular}

Sumber : Data Primer diolah, 2017

Berdasarkan tabel 4.3 diketahui Hal ini berarti bahwakeputusan pembelian bahwa nilai yang diperoleh pada koefisien secara online dapat pengaruhi oleh gaya determinasi (adjusted $R^{2}$ ) sebesar 0,807. hidup, kepercayaan, kemudahan, dan kualitas 
informasi sebesar $80,7 \%$ sedangkan sisanya yaitu $19,3 \%$ dijelaskan oleh variabel lain yang tidak diteliti dalam penelitian ini.

\section{Pembahasan}

Berdasarkan hasil pengujian secara statistik dapat terlihat dengan jelas bahwa secara parsial (individu) variabel bebas gaya hidup, kemudahan, kualita informasi berpengaruh terhadap variabel terikat keputusan pembelian. Pengaruh yang diberikan tiga variabel bebas tersebut bersifat positif.Sedangkan variabel kepercayaan tidak berpengaruh terhadap variabel terikat keputusan pembelian, sehingga pengaruh yang diberikan varibel bebas tersebut bersifat negatif.Hasil tersebut sesuai dengan hipotesis yang diajukan.Penjelasan dari masing-masing pengaruh variable dijelaskan sebagai berikut.

\section{Pengaruh Gaya Hidup terhadap Keputusan Pembelian}

Hasil pengujian hipotesis (H1) telah membuktikan ada pengaruh antara gaya hidup terhadap keputusan pembelian. Melalui hasil perhitungan yang telah dilakukan, diperoleh thitung sebesar 3,610 dengan taraf signifikansi hasil sebesar 0,000 tersebut lebih kecil dari 0,05 dengan demikian Ho ditolak dan Ha diterima. Pengujian ini secara statistik membuktikan bahwa gaya hidup berpengaruh signifikan terhadap keputusan pembelian. Artinya ada pengaruh antara variabel gaya hidup terhadap keputusan pembelian online. Hasil ini sesuai dengan penelitian yang dilakukan Abdilla, Kamener, Rosha (2014) yaitu adanya pengaruh gaya hidup secara positif terhadap keputusan pembelian.

\section{Pengaruh kepercayaan terhadap Keputusan Pembelian.}

Hasil pengujian hipotesis (H2) telah membuktikan tidak ada pengaruh kepercayaan terhadap keputusan pembelian. Melalui hasil perhitungan yang telah dilakukan,diperoleh $\mathrm{t}$ hitung sebesar 0,757 dengan taraf signifikansi hasil sebesar 0,451 tersebut lebih besar dari 0,05 dengan demikian Ho diterima dan
Ha ditolak. Pengujian ini secara statistik membuktikan bahwa kepercayaan tidak berpengaruh terhadap keputusan pembelian. Artinya tidak ada pengaruh antara variabel kepercayaan terhadap keputusan pembelian online.Ini artinya bahwa kepercayaan bukan lagi merupakan faktor yang menjadi pertimbangan utama mahasiswa Universitas Gunadarma dalam memutuskan untuk melakukan pembelian online.Hasil ini sesuai dengan yang dilakukan penelitian oleh Piarna (2014) yaitu tidak adanya pengaruh variabel kepercayaan terhadap keputusan pembelian.

\section{Pengaruh Kemudahan Terhadap Keputusan Pembelian}

Hasil pengujian hipotesis $(\mathrm{H} 3)$ telah membuktikan ada pengaruh kemudahan terhadap keputusan pembelian secara. Melalui hasil perhitungan yang telah dilakukan, diperoleh thitung sebesar 3,740 dengan taraf signifikansi hasil sebesar 0,000 tersebut lebih kecil dari 0,05 dengan demikian Ho ditolak dan Ha diterima. Pengujian ini secara statistik membuktikan bahwa kemudahan berpengaruh signifikan terhadap keputusan pembelian. Artinya ada pengaruh antara variabel kemudahan terhadap keputusan pembelian online.Hasil ini sesuai dengan yang dilakukan penelitian oleh Andromeda (2014) yaitu adanya pengaruh secara positif kemudahan terhadap keputusan pembelian secara online.

\section{Pengaruh Kualitas Informasi Terhadap Keputusan Pembelian}

Hasil pengujian hipotesis (H4) telah membuktikan ada pengaruh kualitas informasi terhadap keputusan pembelian. Melalui hasil perhitungan yang telah dilakukan, diperoleh $\mathrm{t}$ hitung sebesar 3,104 dengan taraf signifikansi hasil sebesar 0,002 tersebut lebih kecil dari 0,05 dengan demikian Ho ditolak dan Ha diterima. Pengujian ini secara statistik membuktikan bahwa kualitas informasi berpengaruh signifikan terhadap keputusan pembelian. Artinya ada pengaruh antara variabel kualitas informasi terhadap keputusan pembelian online.Hasil ini sesuai dengan yang dilakukan 
penelitian oleh Naomi (2012) yaitu adanya pengaruh secara positif kualitas infromasi terhadap keputusan pembelian.

\section{Penutup}

Berdasarkanhasilanalisisdanpembahasan dalam penelitian ini, maka diperoleh simpulan bahwa: Gaya hidup, kepercayaan, kemudahan, dan kualitas informasi secara bersama-sama mempunyai pengaruh signifikan terhadap keputusan pembelian (KP) online. Gaya hidup, kemudahan, dan kualitas informasi berpengaruh terhadap keputusan pembelian, sedangkan kepercayaan tidak berpengaruh secara signifikan terhadap keputusan pembelian online.

\section{Daftar Pustaka}

Abdillah, Marjesi., Dahliana Kamener, dan Zeshasina Rosha. 2014. Pengaruh Gaya Hidup, Kepercayaan Dan Kualitas Informasi Terhadap Keputusan Pembelian Online.Universitas Bung Hatta Padang.

Andromeda, Kevin. 2014. Analisis Pengaruh Kepercayaan, Kemudahan, Dan Keragaman Produk Pakaian Via Online Terhadap Keputusan Pembelian Secara Online. Penelitian Ilmiah Universitas Muhamadiah Semarang.

Assael, H, 1998, Consumer Behavior and Marketing Action, 5th edition, Cincinatti,OH: South Western College Publishing.

Baskara, Isnain Putra dan Guruh Taufan Hariyadi. 2014. Analisis Pengaruh Kepercayaan, Keamanan, Kualitas Pelayanan dan Persepsi Akan Resiko Tehadap Keputusan Pembelian Melalui Situs Jejaring Sosial (Social networking Websites). Jurusan Manajemen. Fakultas Ekonomi. Semarang: Universitas Dian Nuswantoro.

Chen, S. C. and Dhillon, G.S. 2003.'Interpreting Dimensions of Consumer Trust in E-Commerce', Information Technology and Management, 4: 303-313.

Davis, F. D. 1989. Perceived Usefulness, Perceived Ease Of Use, And User Acceptance Of Information Technology. MIS Quarterly, 13(2), 318-340.

Doney, P.M., dan Cannon, J.P., 1997. An Examination of the Nature of Trust in Buyer-Seller Relationship, Journal of Marketing, Vol. 61, April: 35-51

Gefen, David (2002) "Customer Loyalty in E-Commerce," Journal of the Association for Information Systems: Vol. 3 : Iss. 1 , Article 2.

Ghozali, Imam. 2001. Analisis Multivariate Dengan SPSS . Semarang: BP UNDIP

Ghozali, Imam. 2006. Analisis Multivariate Lanjutan Dengan SPSS .Edisi I. Semarang: BP UNDIP

Hardiawan, Anandya Cahya. 2013. Pengaruh Kepercayaan, Kemudahan, dan Kualitas Informasi terhadap Keputusan Pembelian Secara Online pada Pengguna Situs Jual Beli Online tokobagus.com. Skripsi Tidak Diterbitkan. Semarang: UNDIP.

Kotler, Philip dan Kevin Lane Keller. 2009. Manajemen Pemasaran, Edisi 13 Jilid 1. Jakarta : Erlangga

Koufaris, M., Hampton-Sosa, W., (2004), The Development Of Initial Trust In An Online Company By New Customers, Information and Management, January, (41:3),pp. 377397.

Mayer. R. C., Davis, J.D. and Schoorman, F.D. 1995. An Integrative Model of Organisational Trust', Academy of Management Review, 20(3):.709 - 734. 
Naomi, Pube Emma. 2012.Pengaruh Kepercayaan, Kemudahan, Kualitas Informasi, Dan Harga Terhadap Keputusan Pembelian Konsumen Dalam Memilih Berbelanja Secara Online (Studi Pada Pengguna Situs Jual Beli Online Kaskus.Co.Id Di Purworejo). Universita Muhammadiyah Purworejo.

Park C-H dan Kim Y-G. 2003. A Frameworkof dynamic CRM: Linking Marketing With Information Strategy. Business Process Management Journal, 9 (5).652-671 (20).

Pavlou, P. A. \& Geffen, D. (2002). Building Effective Online Marketplaces With InstitutionBased Trust. Proceedings of Twenty Third International Con-ference on Information Systems, 667-675.

Rofiq, Ainur. 2007. Pengaruh Dimensi Kepercayaan (Trust) Terhadap Partisipasi Pelanggan E-Commerce.Universitas Brawijaya Malang.

Rousseau, D., Sitkin, S., Burt, R., \& Camerer, C. 1998. Not so different after all: A Crossdiscipline view of Trust. Academy of Management Review, 23(3): 393-404.

Schiffman, Leon G. dan Lesli Lazar Kanuk. 2000. Consumer Behavior, 7 th. Edition. PrinticeHall, new Jersey.

Suliantoro, Hery. 2012. Adopsi Teknologi E-Procurement Pada Sektor Publik: Sebuah Pengembangan Model Teoritik Melalui Pendekatan Nilai Sosial, Personal Dan Organisasi. Disertasi Doktor, Program Doktor Ilmu Ekonomi Universitas Diponegoro, Semarang.

Turban, E., King, D., Lee, J., \& Viehland, D. (2004).Electronic Commerce: A Managerial Perspective. New Jersey: Pearson Prentice Hall.

Yuniarti, Vinna Sri. 2015. Prilaku Konsumen.Bandung: Pustaka Setia. 